\title{
Aspek-Aspek penting yang terdapat pada Entrepreneur Behavior.
}

\author{
Nama : haqqan amien \\ Email : haqqanamien1@gmail.com
}

Entrepreneurial Orientation atau orientasi kewirausahaan memiliki kemampuan yang inovatif sebagai dasar dalam suatu sumber daya dan menciptakan sebuah peluang untuk menuju sebuah kesuksesan dan memiliki sebuah implikasi positif terhadap suatu kinerja perusahaan. Pada sebuah penelitian terdahulu dapat memperhatikan hubungan positif pada kinerja bisnis dan orientasi kinerja suatu perusahaan. Akan tetapi pengaruh negatif dapat berpengaruh terhadap orientasi kewirausahaan terhadap kinerja bisnis untuk kedepannya. Pada penelitian terdahulu terdapat juga lemahnya hubungan antara kinerja perusahaan dengan orientasi kewirausahaan yang sekarang ini. (Donbesuur, Boso, \& Hultman, 2020)

Inovasi terbuka atau open innovation yaitu sebuah proposif arus masuk dan arus keluar untuk mempercepat inovasi internal dan memperluas pasar untuk eksternal dengan inovasi, masing-masing. Di bawah paradigma inovasi terbuka, batas-batas antara perusahaan dan sekitarnya lingkungan menjadi berpori, memungkinkan inovasi untuk bergerak dengan mudah melintasi mereka. Berdasarkan arah aliran inovasi, studi yang ada membedakan inovasi terbuka sebagai inbound atau outbound Inovasi terbuka inbound mengacu pada sumber dan memperoleh keahlian dari luar organisasi dan memindai lingkungan eksternal untuk informasi baru yang mengidentifikasi, memilih, memanfaatkan, dan menginternalisasi ide-ide. Inovasi terbuka keluar mengacu pada komersialisasi purposif dan menangkap ide-ide yang dikembangkan secara internal dalam lingkungan. Oleh sebab itu, dalam makalah ini mempelajari efek inovasi tentang radikalisasi inovasi. (Lyu, Zhu, Han, He, \& Bao, 2020)

Pengelolaan risiko atau risk governance dengan adanya evaluasi pengelolaan risiko informasi teknologi dimana pada penelitian tersebut menggunakan kerangka kerja COBIT 5 atau mengontrol suatu informasi dan teknologi yang sedang terkait untuk mengetahui tingkat kapabilitas yang telah dicapai guna meningkatkan kemampuan perusahaan dalam menerapkan manajemen risiko Teknologi Informasi. Karena kerangka kerja pada COBIT 5 adalah salah satu kerangka kerja yang paling sering digunakan pada TI Governance yang mendukung keselaarasan TI dengan bisnis. (Hegger, Runhaar, Laerhoven, \& Driessen, 2020)

open innovation atau inovasi terbuka, dalam konteks ini terdapat masalah pada proses pengembangan suatu produk terhadap perusahaan dalam mencapai sumberdaya terbuka, lebih partisipatif, lebih menyebar, dan pendekatan yang lebih terpusat untuk inovasi (Chesbrough, 2003). Dalam menjelaskan konsep (Pratono, 2018) terdapat 4 buah variabel yang menjelaskan tentang Open Innovation. Yang pertama yaitu, Firm Performance yang mengacu pada tingkat pencapaian perusahaan dalam menggapai tujuannya dengan ukuran yang mengacu pada pertumbuhan penjualan, lapangan kerja, laba atas asset, laba atas investasi, dan laba atas penjualan. Yang kedua Network Structure, merupakan bentuk modal sosial yang menjelaskan jaringan kontak perusahaan dalam kepadatan hubungan dan kemampuan yang di gunakan untuk menjangkau jaringan yang berbeda. Yang ketiga Product Development. Yang mengacu 
pada kemampuan suatu perusahaan untuk melakukan innovasi produk dan layanan yang baru akan di tawarkan untuk memenuhi kebutuhan pelanggan dalam mencapai keberlanjutan dalam bisnis. Yang Keempat yaitu Trust, melibatkan hubungan antara pribadi dengan hubungan intra organisasi untuk meningkatkan kualitas dan kuantitas dari pertukaran nasional.

Tingkat pengelolaan risiko UMKM dapat di ukur dengan pemahaman tentang bagaimana perilaku resiko dapat dilakukan secara akurat dan efektif dalam UMKM tidak hanya berguna untuk akademis saja, melainkan praktek UMKM juga berguna untuk kedepannya. Namun terdapat kekurangan dengan temuan empiris implementasi manajmen resiko dalam konteks UMKM dan terdapat 4 hal yang digunakan untuk mengukur tingkat pengelolaan resiko yang terdiri dari perilaku mengambil risiko, kinerja perusahaan, kemampuan harga, dan turbulensi teknologi informasi. (Pratono, 2018)

Donbesuur, F., Boso, N., \& Hultman, M. (2020). The effect of entrepreneurial orientation on new venture performance: Contingency roles of entrepreneurial actions. Journal of Business Research, 118, 150-161. doi:https://doi.org/10.1016/j.jbusres.2020.06.042

Hegger , D. L., Runhaar, H. A., Laerhoven, F. V., \& Driessen, P. P. (2020). Towards explanations for stability and change in modes of environmental governance: A systematic approach with illustrations from the Netherlands. Earth System Governance, 3, 100048. doi:https://doi.org/10.1016/j.esg.2020.100048

Lyu, Y., Zhu , Y., Han, S., He, B., \& Bao, L. (2020). Open innovation and innovation "Radicalness"- the moderating effect of network embeddedness. Technology in Society, 62, 101292. doi:https://doi.org/10.1016/j.techsoc.2020.101292

Pratono, A. H. (2018). Does firm performance increase with risk-taking behavior under information technological turbulence?: Empirical evidence from Indonesian SMEs. The Journal of Risk Finance, 19(4), 361-378. doi:, https://doi.org/10.1108/JRF-10-20170170

Pratono, A. H. (2018). Network structure and open innovation: the role of trust in product development. Business Innovation and Research, 15, 44-61.

Chesbrough, H. (2003) Open Innovation: The New Imperative For Creating And Profiting From Technology, Harvard Business School Press, boston 